\title{
MODULAR ORGANIZATION \\ OF MECHANISMS OF ACHROMATIC VISION \\ IN HUMAN BEINGS AND ANIMALS
}

\begin{abstract}
Aleksander M. Chernorizov, Evgenija D. Shekhter

Lomonosov Moscow State University

Moscow

Psychophysiological research into achromatic vision in humans and vertebrates displays that light intensity is coded by a two-dimensional "excitation vector". The components of that vector are responses of brightness and darkness neurons (or, according to another classification, on- and off-neurons). It means that a current sensation of brightness is determined by a corresponding interrelation between activities of those two systems responding in opponent way to light onset and offset. The present research is devoted to testing of a hypothesis asserting that two-module organization of achromatic vision is a universal principle of brightness coding in a wide raw of animals including invertebrates. The paper represents certain results of registration and analysis of electroretinogram and total activity of the optical nerve in snail Helix lucorum to diffuse light flashes of different intensities. The obtained experimental data, along with the already existing reference data, allow us to assume that on-and off-systems may constitute the neural basis for brightness coding in the invertebrates. The peculiarity of on-and off-systems in vertebrates is that they are formed already at the photoreceptor level.
\end{abstract}

Keywords: achromatic vision, invertebrates, sensations of brightness, electroretinogram, optical nerve, on- and off-systems in vision, "brightness" and "darkness" neuronal modules.

The present research was supported by an NIH Fogarty grant (USA), ERNF grants (USA) and a Research Initiation grant 09-06-00366a from the Russian Foundation for Basic Research. 


\section{Introduction. \\ Formulation of the Subject for Study}

Traditionally, the frequency of impulse activity, the value of interspike intervals or the distribution of action potentials in time domain ("response pattern") are considered as the possible neural code of the light intensity (Batuev \& Kulikov, 1983; Nichols et al., 2003; Smith, 2005). It is not the type of a proposed code, which comes as significant in all these cases, but the assumption that in the central nervous system there exists only one type of neurons specialized in brightness distinguishing; the neurons form a neural system, which cannot be further decomposed into independent (local) modules of neuronal networks. In this paper we consider a fundamentally different approach, linking the mechanisms of brightness distinction to the activity of not one but two independent neural systems - the "brightness" and "dark" - they simultaneously react on the changes in lighting, but their reaction is opposite in mode (Heggelund, 1974; Fomin, Sokolov, \& Vaytkyavichus, 1979; Izmailov \& Sokolov, 1984, 1991). In this case the increase in light intensity leads to excitation of the brightness channel and inhibition of the darkness channel, while the decrease in light causes the reverse effect. So, light intensity can be explicitly determined only by the ratios of contemporary activity of both neural modules. Such a mode of encoding the light intensity by an "excitation vector", whose components are the responses of the dark and brightness neurons, has been designated by the term "vector coding of brightness" (Sokolov, 2003, 2010).

Experimental testing of the hypothesis of vector coding was realized in the psychophysical experiments arranged with human participants, as well as in behavioral and neurophysiological experiments on animals (monkey, rabbit, fish, frog, and mollusk) (for review see: Sokolov, 2003, 2010). In these experiments, the two-channel geometrical models of achromatic vision were built by methods of multidimensional scaling. All the models had the form of two-dimensional sphere (Izmailov \& Sokolov, 1984; Zimachev et al., 1986; Izmailov, Isaichev, \& Shekhter, 1998; Izmailov et al., 2006; Chernorizov, 1999; Chernorizov et al., 2009).

In terms of the neurophysiology, two-dimensionality of geometrical models of achromatic vision of humans and animals can be interpreted as a piece of evidence suggesting that discrimination of achromatic 
(brightness) gradations of lighting involves two opponent neural mechanisms, which apparently are formed at the retina level. For experimental verification of this hypothesis it is very attractive to use the so-called "simple nervous systems", i.e. animals with a primitively constructed visual system, capable to distinguish gradations of brightness of light and not able to differentiate the color and shape of objects. Experiments on such biological models allow us to investigate the mechanisms encoding luminance (achromatic vision) in isolation from the mechanisms engaged in encoding of the color and form. As such a "simple" system we propose to use the visual system of pulmonary snail Helix pomatia L.). Achromatic vision of invertebrates, based on the photopigment "rhodopsin", is analogous to "rod vision" in vertebrates and may serve as a convenient experimental model for studying the mechanisms of the brightness of light encoding independently from encoding of the color (Chernorizov, 1999). Eyes of a snail have the typical structure of the eye ball (Wilbur \& Yonge, 1966; Zaitseva, 1992). They are located in the tops of the head tentacles and are innervated by the optic nerve. Each eye has a cornea, lens, vitreous and the one layer retina. A careful study of the ultrastructure of the eye in Helix pomatia (snail) (Zaitseva, 1992) and Helix aspersa (the closest "relative" of Helix pomatia) (Eakin \& Brandenburger, 1967) identified three types of retinal elements: photoreceptors, supporting cells and neural cells. Since the supporting cells are complementary, and neurons are scarce, the main informational processes in the eye of mollusk seem to be performed by photoreceptors. On the light-directed part they have a microvillus structure, which contains light-sensitive granules of photopigment. Photoreceptors in the snail's eye generate the action potentials. Apart from the cell body, they have long axons that have spike-generating mechanisms. These axons form the optic nerve sending its fibers to the cerebral ganglia. Presumably, the main function of the snail photoreceptors is the localization of the light source when implementing phototropic responses. So, removing the eyes from Helix aspersa (garden snail) and Otala lactea led to the loss of their intrinsic negative phototropism.

The main objective of our work was the testing of the hypothesis that the dark and brightness neural modules may be formed in invertebrates as low as at the retina level. To test this hypothesis, the total activity of the eye (electroretinogram, ERG) and the total electrical activity of the optic nerve in snail Helix pomatia $L$. have been registered and analyzed. 


\section{Methods}

The experiments were conducted in accordance with the international legislation on the use of experimental animals. The researchers were guided by recommendations of the code of ethics adopted by the Council for International Organizations of Medical Sciences and by Russian legislation.

\subsection{Preparation}

The experiments were conducted on a dark-adapted preparation that included an eye, cerebral ganglion, and optical nerve, connecting those structures. Access to the retina was obtained by opening the eyeball and removing the crystalline lens. The preparation was kept in a special lightisolated dish with a standard physiological solution for cold-blooded animals: $80 \mathrm{NaCl}, 4 \mathrm{KCl}, 8 \mathrm{CaCl} 2,5 \mathrm{MgCl}$, 4 Tris- $\mathrm{HCl}$ (pH 7.8) (Sokolov \& Palikhova, 1999).

\subsection{Stimulation}

A computer screen was used as a photostimulator. It provided stimuli - homogenous monochromatic light flashes of different duration (100 ms $\div 3 \mathrm{~s}$ ), brightness (ranging from $2 \mathrm{~cd} / \mathrm{m}^{2}$ to $75 \mathrm{~cd} / \mathrm{m}^{2}$ ) and color. The intensity (brightness) of light stimuli was measured by a brightnessmeter with an error $\pm 5 \%$. As for the color stimuli, standard broadband radiations of color monitor phosphors were employed; these were of three types: the blue phosphor with dominant wavelength of $485 \mathrm{~nm}$, the green phosphor with a dominant wavelength of $530 \mathrm{~nm}$ and a red phosphor with a dominant wavelength of $610 \mathrm{~nm}$. Light-conducting filaments were used to direct the stimuli projection from the screen to a retina preparation. The dark interruption between the presentation of single light stimuli, was not less than 2 minutes $(2 \div 4 \mathrm{~min})$. The interval was determined empirically: experiments with the registration of electroretinogram (ERG) showed it to be the minimum duration of the break between successive stimuli to ensure the maintenance of the dark level of adaptation of the snail eye.

\subsection{Registration activity of the retina and optic nerve}

The electroretinogram was recorded in a monopolar way, when the active electrode was located on the lens and the indifferent one - in the 
saline washing of the preparation. A glass micropipette (tip resistance $\sim 1 \mathrm{mM}$ ) served as the active electrode, it was filled with the saline. The indifferent electrode was a silver non-polarizable electrode. Recorded signals were fed through a cascade of a preamplifier to an oscilloscope CI-103 and, further, to 16-channel analog-digital converter (sampling rate $=250 \mathrm{~Hz}$ ) of the computer IBM Pentium-I, where the registration of bioelectric potentials in computer memory was realized. A special program "Conan" for data collection and statistical analysis (Kulaichev, 2002) was employed for the purpose. Registration of the multipeak extracellular spike activity of the optic nerve was performed under the same conditions as the registration of ERG. The active electrode was a glass electrode (tip diameter $30-40 \mathrm{mkm}$ ) filled with a saturated solution of $\mathrm{KCl}$.

\subsection{Processing and presentation the data}

Treatment of primary electrophysiological data (rejection of artifacts, filtering and averaging of records) was carried out by a special computer program "Conan" (Kulaichev, 2002). Further data analysis and graphing was performed with the aid of the statistical package STATISTICA-5.

\section{Results}

\subsection{Recording and analysis of ERG}

3.1.1. Correlation between the ERG of the snail's eye and the intensity and spectral composition of a light stimuli.

In contrast to the ERG of vertebrates the snail's electroretinogram includes only one component - a corneal-positive component, the latency and amplitude of which in our experiments ranged from $2 \div 3 \mathrm{~s}$ and $0.3 \div 0.9 \mathrm{mV}$, respectively (Fig. $1 \mathrm{~b}$ ).

With the change in light intensity the amplitude of ERG changes nonlinearly. As intensity increases from $1 \mathrm{~cd} / \mathrm{m}^{2}$ to $3.5 \mathrm{~cd} / \mathrm{m}^{2}$ ERG's amplitude increases more rapidly than in the range of $3.5 \mathrm{~cd} / \mathrm{m}^{2}$ to $10 \mathrm{~cd} /$ $\mathrm{m}^{2}$. Under intensities above $10 \mathrm{~cd} / \mathrm{m}^{2}$ increase in the amplitude of ERG is slowed down, and for values above $45 \mathrm{~cd} / \mathrm{m}^{2}$ magnitudes of ERG reach a plateau of saturation. Thus, the region of distinguishing the brightness of light by the snail's eye is limited within the range of $1 \div 45 \mathrm{~cd} / \mathrm{m}^{2}$. 


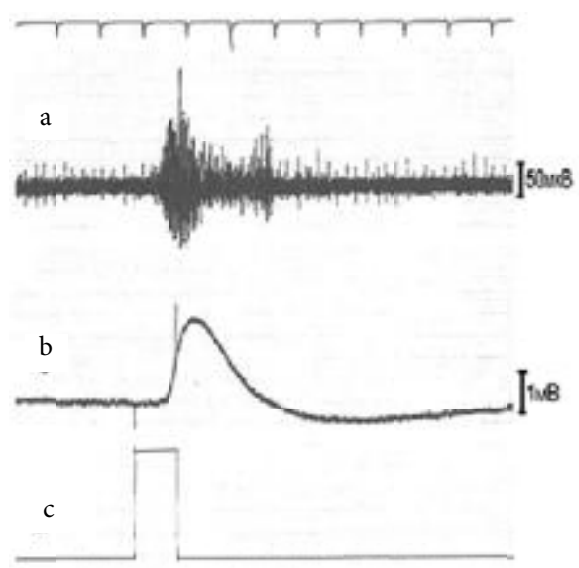

Figure 1. Simultaneous registration of spike-activity of the optic nerve and ERG, while exciting the retina with a light stimulus against darkness adaptation: $\mathrm{a}$ - response of the optic nerve; $\mathrm{b}$-ERG, $\mathrm{c}$ - a stimuli mark.

Calibration: $1 \mathrm{MB}$ for ERG, $50 \mathrm{MKB}$ - for the optic nerve. Time mark - 1 sec.

The upper line represents a time-scale with a fixed grade of $1 \mathrm{sec}$.

The analysis of ERG to light stimuli of different spectral composition suggests that snail's retina is the most sensitive to changes in stimulus intensity of blue color: the amplitude of ERG evoked by blue light greatly exceeds the amplitude of ERG registered for red and green stimuli. The amplitude of ERG for the blue color quickly reaches saturation and has a lower threshold that equals in the conditions of our experiments $1 \mathrm{~cd} / \mathrm{m}^{2}$.

3.1.2. Correlation of the ERG of Halix pomatia with the duration of the light stimulus.

In order to further analyze the properties of the total electrical activity of the snail's eyes the blue stimuli of fixed intensity $\left(7.5 \mathrm{~cd} / \mathrm{m}^{2}\right)$ and variable duration (3s, 5s, 10s and 20s) were used. As it is displayed in Fig. $1 \mathrm{~b}$ and Fig. $2 \mathrm{a}$, the main component of the snail ERG is a positive wave, attached to an onset of the stimulus. In accordance with the generally accepted classification of light responses introduced by H.K. Hartline (1940), we identified this wave as the "on"-response, or the "on"-peak (abbreviated from "onset"). 

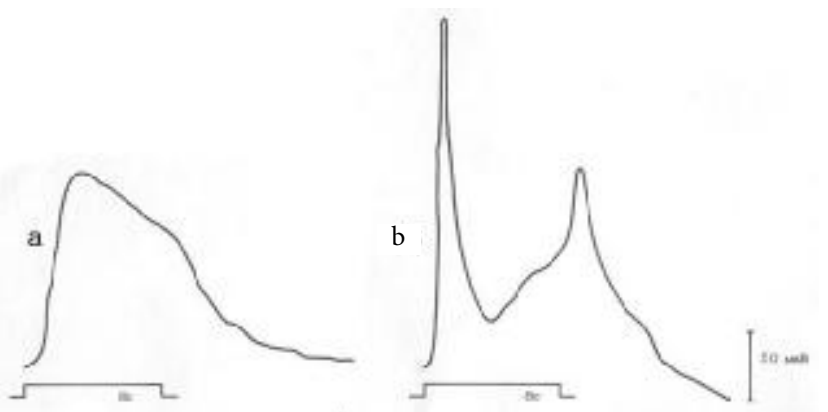

Figure 2. ERG of Helix pomatia (a) and a frog (b) recorded for a diffusive flash of one and the same colour (green), intensity $\left(10 \mathrm{~cd} / \mathrm{m}^{2}\right)$ and length $(8 \mathrm{sec}$.$) . Calibration - 50 \mathrm{MKB}$

Latency, amplitude and shape of the leading edge of "on"-peak do not depend on the duration of light stimuli. The on-peak is followed by the slow decay of the response. One can see a clear dependence of the duration of this slow decay of response on the duration of a stimulus: it increases with the increasing duration of stimulation.

A characteristic difference of snail's ERG from the ERG of vertebrates is that in the former a response to offset of light is absent at any duration and intensity of stimulation. This specificity is illustrated in Fig. 2, where the records of snail's ERG and frog's ERG are demonstrated in a comparative way. Figure 2 shows that, unlike that of a snail, frog's ERG, as well as other vertebrates, consists of both on- and off-components.

\subsection{Light-induced summary activity of snail's optic nerve}

The optic nerve connects the retina with cerebral ganglia of snail's ganglion nervous system (Zaitseva, 1992). Individual optic nerve fibers are mainly axons of photoreceptor cells. So, unlike the photoreceptors of vertebrates, the snail's photoreceptors have the ability to generate action potentials (Vinnikov, 1971). In darkness snail's optic nerve is not active. But illumination makes its fibers generate multi-peak discharges presented by action potentials with the average amplitudes $35 \mathrm{mV}, 50$ $\mathrm{mV}$ and $75 \mathrm{mV}$. One can assume that these three types of action poten- 
tials are generated by three types of fibers of the optic nerve, so we provisionally designated them as fibers of type I, II and III. Table 1 shows the correlation of responses of these three types of fibers with the intensity of light stimulation.

Table 1

Correlation of spike responses of three types of fibers in snail's optic nerve with the intensity $\left(\mathrm{cd} / \mathrm{m}^{2}\right)$ of light stimulus $(\lambda=496 \mathrm{~nm}$, duration $=8 \mathrm{~s})$

\begin{tabular}{|c|c|c|c|}
\hline \multirow{2}{*}{$\begin{array}{c}\text { Intensity } \\
\text { of stimulus } \\
\left(\mathrm{cd} / \mathrm{m}^{2}\right)\end{array}$} & \multicolumn{3}{|c|}{ Number of spikes in the responses of three types fibers (I, II, III) } \\
\hline & $\begin{array}{c}\text { Fibers generating } \\
\text { spikes with amplitude } \\
35 \mathrm{mkV} \text { (type I) }\end{array}$ & $\begin{array}{c}\text { Fibers generating } \\
\text { spikes with amplitude } \\
50 \mathrm{mkV} \text { (type II) } \\
\end{array}$ & \begin{tabular}{|c|} 
Fibers generating \\
spikes with amplitude \\
$75 \mathrm{mkV}$ (type III) \\
\end{tabular} \\
\hline 1.5 & 25 & \begin{tabular}{|c|}
2 \\
\end{tabular} & \begin{tabular}{|c|}
0 \\
\end{tabular} \\
\hline 5.0 & 32 & 8 & 2 \\
\hline 9.0 & 39 & 8 & 3 \\
\hline 14.0 & 40 & 12 & 2 \\
\hline 21.5 & 43 & 10 & 3 \\
\hline 30.0 & 51 & 52 & 30 \\
\hline
\end{tabular}

As it is demonstrated by Table 1, the fibers of type I, which generate low-amplitude action potentials $(35 \mathrm{mV})$, possess the maximal absolute light sensitivity. At the same time, the fibers of types II and III exhibit increased (in comparison with the fibers of type I) differential light sensitivity to changes in light intensity.

Table 2 presents data on the dynamics of spike activity of three types of fibers in the course of the light signal.

Table 2 demonstrates that responses of type I fibers are phase-tonic, as responses of types II and III fibers have a distinct phasic character. From the analysis of temporal distribution of AP in the responses we may also conclude that three types of fibers have different ability to light adaptation, characterized by different dynamics of reducing the density of AP in the course of a light stimulus. Table 2 shows that this ability is maximally expressed in phasic fibers of II and III types.

In our experiments simultaneous recording of ERG and optic nerve action potentials was carried out. Some examples of such simultaneous recordings are shown in Fig. 1 and Fig. 3. Records, similar to those given in the figures, indicate that the latency of ERG $200 \mathrm{~ms}$ is longer than the 
latency of optic nerve response. The length of this 'time lag' remains unchanged with increasing intensity stimuli, when latency values of each of the two types of responses, as a natural result, decrease.

Per second distribution of the number of action potentials (AP) in the responses of three types of fibers of the optic nerve in the course of a light stimulus duration of 8 seconds. The numerical values of AP were obtained by averaging the results of three presentations of the same stimulus $\left(\lambda=496 \mathrm{~nm}, 9 \mathrm{~cd} / \mathrm{m}^{2}\right)$

\begin{tabular}{|c|c|c|c|}
\hline $\begin{array}{c}\text { The time elapsed } \\
\text { from the onset of } \\
\text { the stimulus (s) }\end{array}$ & $\begin{array}{c}\text { Number of AP with } \\
\text { amplitude of 35 } \mathbf{~ m V} \\
\text { (fibers of type I) }\end{array}$ & $\begin{array}{c}\text { Number of AP with } \\
\text { amplitude of 50 } \mathbf{~ m V} \\
\text { (fibers of type II) }\end{array}$ & $\begin{array}{c}\text { Number of AP with } \\
\text { amplitude of 75 } \mathbf{~ m V} \\
\text { (fibers of type III) }\end{array}$ \\
\hline $\mathbf{1}$ & 4 & 0 & 0 \\
\hline $\mathbf{2}$ & 18 & 6 & 3 \\
\hline $\mathbf{3}$ & 25 & 3 & 0 \\
\hline $\mathbf{4}$ & 19 & 2 & 0 \\
\hline $\mathbf{5}$ & 15 & 1 & 0 \\
\hline $\mathbf{6}$ & 9 & 0 & 0 \\
\hline $\mathbf{7}$ & 9 & 0 & 0 \\
\hline $\mathbf{8}$ & 8 & 0 & 0 \\
\hline
\end{tabular}

Analysis of the light-induced responses of the optic nerve shows that, in contrast to the ERG, the overall response to light of the optic nerve comes in two phases, i.e. is represented by two bursts of spike discharges, separated by an interval of relatively low activity (Fig. 1). The first phase of this response similarly to described above "on"-component in the ERG is associated with the onset of a light stimulus. In accordance with commonly adopted and mentioned above terminology coined by Hartline (1940) this first phase may be designated as "on"-response of the optic nerve to a light flash. The second burst of spike activity of the optic nerve coincides in time domain with the return of the ERG to the background level registered under dark adaptation (before light stimulation). The "on"-component of the response of the optic nerve is obviously connected with the moment of the light onset. But to prove the connection of the second phase with stimulation parameters additional experiments were required. In these we tested the following hypothesis: the second phase of the response of the optic nerve is a response to the offset of the light stimulus (that is, 
“off"-response). In the course of testing a relationship between the time of appearance of the second phase of the response and the moment of switching off the light has been studied, under varying duration of stimulation, which determines the cut-off time of the light stimulus. As a result (anticipated by the hypothesis), it was found that increasing duration of the fixed-intensity light stimulus from $100 \mathrm{~ms}$ to $36 \mathrm{~s} \mathrm{leads}$ to an increase in latency of the second phase of the spike activity of the optic nerve (Fig. 3).

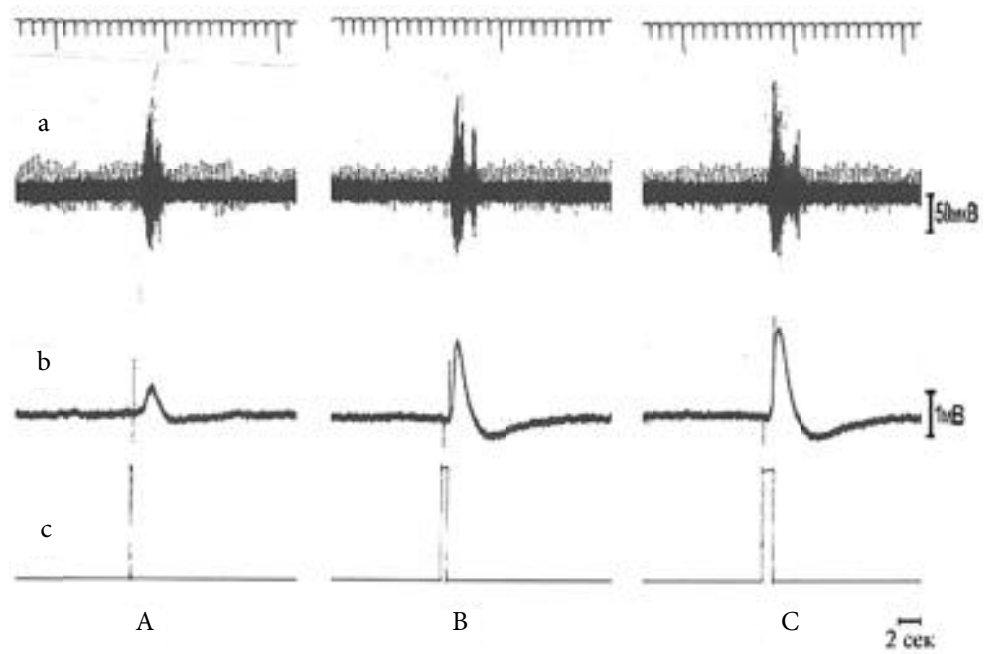

Figure 3. Simultaneous registration of responses of the optic nerve (a) and ERG (b) fro light stimuli of different length. Parameters of stimulation (mark b): blue light of constant intensity $\left(7,5 \mathrm{~cd} / \mathrm{m}^{2}\right)$ and different length (A $100 \mathrm{~ms}, \mathrm{~B}-500 \mathrm{~ms}, \mathrm{C}-1 \mathrm{sec}$ ). Calibration: $1 \mathrm{MB}$ for ERG, $50 \mathrm{mcB}$ for the optic nerve. The time mark $-2 \mathrm{sec}$. The upper line indicates the time scale with a fixed grade of 1 sec.

\section{Consideration}

The present study of the total activity of the retina (ERG) and optic nerve suggests that the peripheral part of the visual system of Halix pomatia is capable of distinguishing sufficiently small differences in light intensity. It was found that the maximum brightness of differential sensitivity lies in the region of blue colors. This is fully consistent with the fact 
that the photoreceptors in the snail's retina contain only one photopigment - rhodopsin, the optimum absorption which falls on the blue-green range of the visible spectrum with a peak at $490-500 \mathrm{~nm}$ (Von Berg, Shneider, 1972; Chernorizov et al., 1992). Another factor that characterizes the sensitivity of the snail to light is the nonlinearity of the dependence between the intensity of the light signal and the response amplitude of the retina. Thus, with increasing light intensity from $1 \mathrm{~cd} / \mathrm{m}^{2}$ to $3.5 \mathrm{~cd} /$ $\mathrm{m}^{2}$ ERG the amplitude increases more rapidly than in the range of 3.5 $\mathrm{cd} / \mathrm{m}^{2}$ to $10 \mathrm{~cd} / \mathrm{m}^{2}$. Under intensities above $10 \mathrm{~cd} / \mathrm{m}^{2}$ increasing of the ERG slows and its amplitude reaches a plateau at some maximal value. Correlation of such kind approaches the logarithmic function that obviously makes the snail able to detect the slightest changes in ecologically important for it range of small luminance values and ignore differences in the region of high brightness. Ecological adaptability (specialization) of this kind is one of the general laws of functioning of all sensory systems (Keidel, 1975).

Lighting of the snail's eye evokes electric activity in the retina, integrally recorded as an electroretinogram (ERG). This response is a corneal-positive wave, characterized by high latency and relatively slow rate of increase (leading front) and fall (falling edge) signal (Fig. 1-3) (Shekhter et al., 1992). Such a structure of the snail's ERG is similar to ERG in other species of molluscs (Gillary, 1970; Zhukov \& Gribakin, 1990).

Which cellular structures are sources of the snail's ERG? In vertebrates, the logarithmic dependence of the response on the light intensity is already observed at the photoreceptor level (Smith, 2005). The photoreceptor origin of snail ERG is evidenced by its shape, which resembles the shape of the intracellular responses of a single photoreceptor (Brown \& Flaming, 1977). The same simple form of ERG can be as well registered in the eyes with complicated retinas (e.g., that of a frog or a cat), when using certain effects to exclude the functioning of cells in the internal nuclear layer, we maintain the normal functioning of photoreceptors (Brown, 1968).

Having only one visual pigment "rhodopsin" the photoreceptors of the snail, however, are heterogeneous both morphologically and functionally. Morphologically, in accordance with the size of microvillus apparatus, photoreceptors in the snail retina are divided into two types. The first type, characterized by large size of the microvillus apparatus, dominates in the retina (up to 3800 cells). 
Photoreceptors of the second type, bearing short and irregular microvillus, are not so numerous (75-200 units) (Eakin \& Brandenburger, 1967). Functionally photoreceptors of the snail are also heterogeneous, since some of them respond to light by depolarization, and another ones - by hyperpolarizing shift of the background (dark) level of the membrane potential (Chernorizov, 2006; Chernorizov et al., 2007; Shekhter \& Grechenko, 2009; Chernorizov \& Sokolov, 2010). Since this result is obtained not only on the intact retina, but also in the intracellular study of completely isolated cells it can be argued that the sign of a photoreceptor responses (de- or hyperpolarization) in the snail is determined endogenously, i.e., by properties of the photoreceptors themselves (Chernorizov, 2006; Chernorizov et al., 2007; Schekhter \& Grechenko, 2009; Shekhter et al., 2010; Chernorizov \& Sokolov 2010; Izmailov \& Chernorizov, 2010).

Despite the fact that the potentials of individual photoreceptors in the snail have opposite polarity (de - or hyperpolarization), the total electrical response of the retina (ERG) is monopolar and consists of a single cornea-positive wave. This can be explained as follows. The latency of light responses in both types of photoreceptors is approximately the same, but the hyperpolarizing type of cells forms a relatively small portion of photoreceptors: according to our data (Shekhter \& Grechenko, 2009 ) only $28 \%$ of the isolated cells exhibit this type of responses. Consequently, in the integral form (ERG), activity of this cell type may be disguised by dominant activity in retinal photoreceptors, which are being hyperpolared by light. One can further assume that these two types of photoreceptors constitute "brightness" (depolarizing by light) and "darkness" (hyperpolarizing by light) elements in the retina. If this happens to be true, then the lack of manifestations of the off-effect to offset of light in the snail's ERG is due not to the lack of 'darkness systems' in the retina of the snail, but its being camouflaged by dominating activity of 'brightness' system.

Yet another feature of photoreceptors in the snail is the combination of two functions in one cell of the receptor: a receptor function as such, and primary sensory neuron function, because their axons have a spike-generating mechanism. These axons form the optic nerve transferring signals to CNS. Light stimulation of the eyes is accomplished by an asynchronous activity of optical fibers as discovered in the total burst activity of the optic nerve consisting of action potentials of different am- 
plitudes (Fig. 1, 3; Tables 1-2). Our electrophysiological data indicate the existence of at least three types of fibers in the optic nerve - slow adapting phase-tonic (type I fibers) and rapidly adapting phasic (types II and III fibers). This is consistent with morphological studies that the snail's optic nerve contains multiple populations of fibers varying in diameter and, consequently, the speed of an electric signal conductance (Zaitseva, 1992).

In response to a light stimulation the appearance of action potentials in the optic nerve goes ahead of the electroretinogram. Such kind of a time-lag between responses of single cells and ERG may indicate the presence of glial cells in the snail's retina, which in vertebrates are direct issues of the total activity of the retina (Nicholls et al., 2003). The $\mathrm{K}^{+}$- dependent responses of these slowly triggered glial cells, apparently, lead to a delay in expression of signals from photoreceptors and neurons in ERG. In this regard, the snail's ERG is similar to the ERG of vertebrates, which is a direct reflection of the responses of retinal glial cells - so-called Mueller cells (Nicholls et al., 2003; Chernorizov, 2008).

In contrast to the ERG, the light-induced activity of the optic nerve contains both on-response to the onset of light, and off-discharges following the shutting down of the stimulus. These responses seem to belong to different populations of nerve fibers, being represented by action potentials of different amplitudes (Fig. 1,3). If the on-response is characterized by relatively high-amplitude action potentials (AP) in type I fibers, the off-response involves low-amplitude AP generating in types II and III fibers. Furthermore, as compared with on-responses, off-response is as a rule less pronounced, indicating that there is a relatively small number of off-elements in the retina which respond to light off. This allows us to relate the origin of the off-response of the optic nerve to the activities of a small portion of photoreceptors, hyperpolarized by light, and, respectively, depolarized by its turn-off: this depolarizing response to turn-off of a light is, strictly speaking, an off-response.

Thus, our experiments provide empirical grounds to assert that achromatic visual system of the snail Helix pomatia, comprised of "brightness" and "darkness" subsystems, starts to emerge already at the level of photoreceptors. It is not at all impossible, that in the final formation of these two opponent to each other coding subsystems, there are also engaged neurons in the neuropil at the basis of the optic nerve, where, 
in addition, direct morphological interconnections between collaterals photoreceptors themselves have been found (Zaitseva, 1992).

In visual systems of the animals, multi-layered retina of which is much more complicated than that of the snail, "brightness" and "darkness" channels are formed beyond the photoreceptors at the higher cellular levels. Notably, in fish the activity of these channels are first detected in the networks of bipolar cells in the inner nuclear layer of the retina (Chernorizov, 1999; Chernorizov \& Sokolov, 2001). On the other hand, mollusk Onchidium, though much simpler organized, than a snail, is distinguished by the fact that its brightness and dark systems are not integrated in the retina (as in the snail), but distributed in two morphologically different organs of vision: its cephalic eyes provide discrimination of brightness / shadows, whereas the dorsal eye on the bottom surface of the Onchidium's body provide the response to a blackout (Katagiri et al., 1985).

\section{Conclusion}

Visual system of humans and different animals may use different "tactics" for the formation of "brightness" and "darkness" neural systems: in vertebrates, these modules are formed at the level of the retinal neurons (starting with bipolar cells) and in invertebrates they already are constructed at the level of the photoreceptors. However, the principle of opponence of "brightness" and "darkness" systems in the functioning of mechanisms, encoding the intensity of the light, apparently, is universal for both vertebrate and invertebrate animals. Our own results, as well as the reference data, allow hypothesizing that the neural basis for distinguishing the brightness is a consistent (weighted) activity of "on"- and "off"- neurons in visual system.

\section{References}

Batuev, A.S., \& Kulikov, G.A. (1983). Vvedenie v fiziologiyu sensornykh system [Introduction to the physiology of sensory systems]. Moscow: Vysshaya shkola.

Brown, K.T. (1968). The electroretinogram: its components and their origins. $\mathrm{Vi}$ sion Research, 8(6), 633-677.

Brown, K.T., \& Flaming, D.G. (1977). Intracellular recording in outer segments of red and green rods of the toad. Society for Neuroscience Abstracts, 3, 554. 
Chernorizov, A.M. (1999). Neyronnye mekhanizmy tsvetovogo zreniya [Neural mechanisms of color vision]: Avtoref. dis. ... d-ra psykchol. nauk. Moscow.

Chernorizov, A.M. (2006). Eksperimental'noe issledovanie I modelirovanie neyronnykh mekhanizmov akhromaticheskogo zreniya moluska Helix lucorum L. [Experimental study and modeling of neural mechanisms of achromatic vision in snail Helix lucorum L.]. Zhurnal Neurocomputers, 4-5, 78-89.

Chernorizov, A.M. (2008). Gliya: morfologiya, fiziologiya, funktsii [Glia: morphology, physiology, functions]. In E.N. Sokolov, A.M. Chernorizov, V.A. Filippov (Eds.), Nejron [Neuron] (ch. 18, pp. 433-467). Moscow

Chernorizov, A.M., Shekhter, E.D., Arakelov, G.G., \& Zimachev, M.M. (1992). Zrenie vinogradnoy ulitki: spektral'naya chuvstvitel'nost' temnoadaptirovannogo glaza [Vision in snail: spectral sensitivity of dark-adapted eye]. Zhurnal Vysshei Nervnoy Deyatel'nosti imeni Pavlova, 42(6), 1150-1156.

Chernorizov, A.M., \& Sokolov, E.N. (2001). Vektornoe kodirovanie tsveta v sloe bipolyarnykh kletok setchatki karpa [Vector encoding of color in the layer of bipolar cells in the carp retina]. Vestnik MGU. Seriya 14, Psikhologiya, 1, 12-33.

Chernorizov, A.M., Zimachev, M.M., Shekhter, E.D., \& Garusev, A.V. (2007). Mekhanizmy akhromaticheskogo zreniya molluska Helix Lucorum L.: dannye vnutrikletochnogo issledovaniya svetochuvstvitel'nukh kletok setchzatki. [Mechanisms of achromatic vision in snail Helix Lucorum L.: data of intracellular research into light-sensitive cells of the retina]. Zhurnal Vysshei Nervnoy Deyatel'nosti imeni Pavlova, 1, 701-707.

Chernorizov, A.M., Shekhter, E.D., Grechenko, T.N., \& Garusev, A.V. (2009). Psikhofiziolgiya akhromaticheskogo zreniya: ot prostykh nervnykh sistem k cheloveku [Psychophysiology of achromatic vision: from simple neural networks to human]. In Psikhologiya cheloveka $v$ sovremennom mire [Psychology of human in the modern world] (vol. 4, pp. 370-377). Moscow: IP RAN.

Chernorizov, E.N., \& Sokolov, E.N. (2010). Mechanisms of Achromatic Vision in Vertebrates and Invertebrates: A Comparative Study. The Spanish Journal of Psychology, 13(1), 18-29.

Eakin, R.M., \& Brandenburger, J.L. (1967). Differentiation in the eye of a pulmonate snail Helix aspersa. Journal of Ultrastructure Research, 18(4), 391-421.

Fomin, S.V., Sokolov, E.N., \& Vaytkyavichus, G.G. (1979). Iskusstvennye organy chuvstv [Artificial senses]. Moscow: Nauka.

Gillary, H.L. (1970). Electrical responses from the eye of Helix to photic stimulation and simultaneous electrical stimulation of the optic nerve. Vision Research, 10(10), 977-991.

Hartline, H.K. (1940). The nerve messages in the fibers of the visual pathway. Journal of Optical Socience of America, 30, 239-247.

Heggelund, P. (1974). Achromatic color vision. I. Perceptive variables of achromatic colors. Vision Research, 14, 1071-1079. 
Izmailov, Ch.A., \& Sokolov, E.N. (1984). Tsvetovoe zrenie [Color vision]. Moscow: Izd-vo Mosk. un-ta.

Izmailov, Ch.A., \& Sokolov, E.N. (1991). Spherical model of color and brightness discrimination. Psychological Science, 2, 249-259.

Izmailov, Ch.A., Isaichev, S.A., \& Shekhter, E.D. (1998). Dvukh-kanal'naya model' razlicheniya signalov v sensornykh sistemakh [Two-channel model of distinguishing signals in sensory systems]. Vestnik MGU. Seriya 14, Psikhologiya, 3, 29-40.

Izmailov, Ch.A., Zimachev, M.M., Sokolov, E.N., \& Chernorizov, A.M. (2006). Dvukh-kanal'naya model' akhromaticheskogo zreniya lyagushki [Two-channel model of the frog's achromatic vision]. Sensornye Sistemy, 20(1), 1-11.

Izmailov, Ch.A., \& Chernorizov, A.M. (2010). A Geometrical Approach to Research into Signal Recognition in Visual Systems of Humans and Animals. In Yu.P. Zinchenko \& V.F. Petrenko (Eds.), Psychology in Russia: State of the Art (pp. 301-332). Moscow: MGU \& IG-SOCIN.

Katagiri, Y., Katagiri, N., \& Fujimoto, K. (1985). Morphological and electrophysiological studies of a multiple photoreceptive system in a marine gastropode Onchidium. Neuroscience Research, 2, 1-15.

Keidel, V.D. (1975). Fiziologiya organov chuvstv [Physiology of sensory systems]. Moscow: Meditsina.

Kulaichev, A.P. (2002). Komp'yuternaya elektrofiziologiya [Computer electrophysiology]. Moscow: Izd-vo Mosk. un-ta.

Nicholls, J.G., Martin, A.R., Wallace, B.J., \& Fuchs, P.A. (2003). Ot nejrona k mozgu [From neuron to the brain]. Moscow: Editorial URSS.

Smith, K. (2005). Biology of Sensory Systems, Chichester, New York, Weinheim, Brisbane, Toronto, Singapore: John Wiley \& Sons.

Sokolov, E.N. (2003). Vospriyatie I uslovnyy refleks. Novyy vzglyad [Perception and the conditioned reflex. New approach]. Moscow: URSS.

Sokolov, E.N. (2010). Ocherki po psikhofiziologii soznaniya [Essays on psychophysiology of consciousness]. Moscow: Izd-vo Mosk. un-ta.

Sokolov, E.N., \& Palikhova, T.N. (1999). Immediate plasticity of identifiable synapses in the land snails Helix lucorum. Acta Neurobiolology Experimentale, 59, 161-169.

Shekhter, E.D., Zimachev, M.M., \& Arakelov G.G. (1992). Zrenie molluska. Morfologiya i summarnaya elektricheskaya aktivnost' setchatki [Vision of the snail. Morphology and total electrical activity of the retina]. Zhurnal Vysshei Nervnoy Deyatel'nosti imeni Pavlova, 42(5), 986-991.

Shekhter, E.D., \& Grechenko, T.N. (2009). Dva tipa fotoretseptorov v akhromaticheskoy zritel'noy sisteme vinogradnoy ulitki [Two types of photoreceptors in achromatic visual system of Helix pomatia L.]. Eksperimental'naya psikhologiya, 2(2), 5-15.

Vinnikov, Y.A. (1971). Tsitologicheskie i molekulyarnye osnivy retseptsii [Cytological and molecular basis of the reception]. Leningrad: Nauka. 
Von Berg, E., \& Shneider, G. (1972). The spectral sensitivity of the dark-adapted eye of Helix pomatia. Vision Research, 12(12), 2151-2152.

Wilbur, K.W., \& Yonge, C.M. (Eds.) (1966). Physiology of mollusca (vol. II). New York, London: Academic Press.

Zaitseva, O.V. (1992). Strukturnaya organizatsiya sensornykh sistem ulitki [Structural organization of sensory systems in the snail]. Zhurnal Vysshei Nervnoy Deyatel'nosti imeni Pavlova, 42(6), 1132-1150.

Zhukov, V.V., \& Gribakin, F.G. (1990). Cpektral'naya chuvstvitel'nost' glaza molluskov v ultrafioletovoy i vidimoi oblasti spectra [Spectral sensitivity of the eyes of mollusks in the ultraviolet and visible spectral region]. Sensornye Sistemy, 4 (4), 341-350.

Zimachev, M.M., Shekhter, E.D., Sokolov, E.N., \& Izmailov, Ch.A. (1986). Khromaticheskaya sostavlyayushchaya elektroretinogrammy lyagushki [Chromatic component of the frog electroretinogram]. Zhurnal Vysshei Nervnoy Deyatel'nosti imeni Pavlova, 36(6), 1100-1107. 